\title{
Law, Society, and Violence in the Antebellum Midwest: The 1857 Eastern Iowa Vigilante Movement
}

\author{
MiChAEL J. PfEIFER
}

FROM APRIL THROUGH DECEMBER 1857, a large-scale vigilante movement swept across the late midwestern frontier of eastern Iowa.' Eventually encompassing five counties, the movement collectively killed 16 white men who were accused of murder, horse theft, and counterfeiting. The movement and the opposition it elicited highlighted changing antebellum midwestern notions of law and authority, class, culture, and community. In the east central counties that adjoined the Mississippi River and its tributaries, Iowans helped to lethally and fatefully

I am grateful for a State Historical Society of Iowa Research Grant that funded the research and writing of this article. Robert R. Dykstra, Marvin Bergman, and an anonymous reader offered valuable comments on an earlier draft.

1. I use the phrase late midwestern frontier to connote the late antebellum dynamics in eastern lowa in which substantial in-migration and cultural and social formation were occurring even though white settlement was already several decades old. Much of eastern Iowa had experienced its initial white settlement in the period from 1831 to 1850; central and western portions of the state would see settlement in the decades from 1840 through 1870. For the chronology of settlement and the origins of midwestern regions, see Robert $C$. Ostergren, "Geographical Perspectives on the History of Settlement in the Upper Midwest," Upper Midwest History 1 (1981), 27-39. Antebellum political, social, and cultural formation in Iowa is treated in Robert R. Dykstra, Bright Radical Star: Black Freedom and White Supremacy on the Hawkeye Frontier (Cambridge, MA, 1993).

THE ANNALS OF IOWA 64 (Spring 2005). (C) The State Historical Society of Iowa, 2005. 
transform traditions of collective violence that were rooted in an ideology of popular sovereignty and a praxis of informal, popular punishments bequeathed by early modern Anglo-American folk culture and the American Revolution.

The vigilantes in Iowa in 1857 acted not in the absence of legal institutions, which were already well established in the region, but because a changing legal system offered tenuous and unsatisfying solutions to problems of authority and social control in a region where lines of social hierarchy, culture, and community leadership were ambiguous and undefined. Midnineteenth-century advocates of vigilantism in Iowa drew on Anglo-southern and American revolutionary traditions of community violence that suggested that citizens might reclaim the functions of government when legal institutions could not provide sufficient protections to persons or their property. The Iowa vigilantes' highly instrumentalist practice highlighted distinctions within communities between the now respectable and the now unrespectable: alleged murderers and transgressors of property, such as horse thieves, counterfeiters, and claims jumpers. ${ }^{3}$

In their temporary, republican usurpation of the prerogatives of legal authority, the Iowa vigilantes invoked popular sovereignty to reject a style and philosophy of criminal justice that had crystallized in the Northeast from the late eighteenth through the mid-nineteenth centuries. Legal changes emanating from the Northeast included a newly ascendant respect for the rights of the defendant (enshrined in the Fifth Amendment to

2. For an overview of the history of American vigilantism and its roots in the American revolutionary era, see Richard Maxwell Brown, Strain of Violence: Historical Studies of American Violence and Vigilantism (New York, 1975), esp. 4166. The ideology and practice of collective violence, particularly rioting, in the revolutionary era, is considered in Paul A. Gilje, Rioting in America (Bloomington, IN, 1996), 35-59.

3. An influential interpretation of the claim clubs, organizations that sought to punish alleged claims jumping on the lowa frontier, is in Allan G. Bogue, "The Iowa Claim Clubs: Symbol and Substance," Mississippi Valley Historical Review 45 (1958), 231-53. Claim clubs employed relatively mild forms of violence, such as tar-and-feathering, in contrast to the lethal means of shooting and hanging employed by the eastern Iowa vigilantes in 1857. For a recent interpretation that stresses how non-lethal vigilantism in Keokuk in the late 1830s and early to mid-1840s served to draw social boundaries and to consolidate community and economic and social networks, see Timothy R. Mahoney, Provincial Lives: Middle-Class Experience in the Antebellum Middle West (Cambridge, 1999), 73-81.' 
the U.S. Constitution, holding that no citizen would be deprived of due process protections), a burgeoning interest in the potential for the reform of the criminal, and a fear of the effects of harsh punishments on the masses that enthusiastically viewed them. The reform of criminal justice in line with humanitarian considerations and a growing emphasis on legal rights and fairness accompanied capitalist transformation and middle-class and working-class formation in the Northeast from the American Revolution through the first half of the nineteenth century. ${ }^{4}$

The adversary system, in which lawyers dominated trials and vigorously contested criminal procedure, was also a recent development in the history of criminal justice, taking root in Anglo-American law only in the eighteenth century. ${ }^{5}$ As with movements to limit capital punishment, the adversary system took fullest root in the Northeast. The middle-class residents of that region were committed to due process principles and the reform of criminal justice institutions and accepted the necessity of aggressive lawyering in the interest of legal fairness.

Still, cohesive urban working-class communities continued to acquit or convict defendants in line with traditional understandings of community justice. ${ }^{6}$ In the South, whites persisted in observing customary communal notions of justice for whites in and out of court, evinced comparatively little interest in legal reform, and sought to keep African American slaves out of court and instead subject to the punitive whims of the slaveholding class and the larger white community. ${ }^{7}$ Complaints about an

4. For the transformation of criminal justice in the context of the death penalty in the Northeast, see Louis P. Masur, Rites of Execution: Capital Punishment and the Transformation of American Culture, 1776-1865 (New York, 1989); and Stuart Banner, The Death Penalty: An American History (Cambridge, MA, 2002), 88-141.

5. John H. Langbein, The Origins of Adversary Criminal Trial (New York, 2003).

6. Elizabeth Dale, "Northerners and their Laws: Legal Pluralism in Antebellum Era Philadelphia" (unpublished manuscript in author's possession).

7. These tendencies in local criminal justice in the South are analyzed perceptively in an introduction and essays by Sally Hadden, Timothy S. Huebner, Judith Kelleher Schafer, and Ariela Gross in Christopher Waldrep and Donald G. Nieman, eds., Local Matters: Race, Crime, and Justice in the Nineteenth-Century South (Athens, GA, 2001), ix-124. Banner, The Death Penalty; 137-43, analyzes the relatively minor reform of capital punishment in the antebellum South; he argues that slavery thwarted the development of the significant culture of reform that emerged in the North. For a treatment of antebellum criminal justice in Missis- 
overabundance of lawyers and their intolerable manipulation of the legal process abounded on the backwoods southern frontier, sometimes inspiring regulator movements. ${ }^{8}$ Clearly, then, southerners in the early republic and the antebellum era had not committed fully to due process law or to the adversary system that supported it.

The story was more complex, however, on the midwestern frontier, where Yankees and settlers from the Old Northwest and upper South wielded competing notions of criminal justice. Frontier Iowans with roots in New England and the mid-Atlantic tended to stress legal regularity and due process, whereas those Iowans who came from border regions and the South emphasized harsh and rapid punishment that coincided with communal prerogatives. Many Iowans came from Ohio and Indiana, which included both northern regions culturally dominated by Yankees and "Butternut" regions settled from the upper South. Antebellum eastern Iowans' clashing cultural perspectives on law inspired the wave of collective violence and the debate that surrounded it in $1857 .^{9}$

sippi, see Christopher Waldrep, Roots of Disorder: Race and Criminal Justice in the American South, 1817-1880 (Urbana, IL, 1998), 7-58. Michael S. Hindus, Prison and Plantation: Crime, Justice, and Authority in Massachusetts and South Carolina, 1767-1868 (Chapel Hill, NC, 1980), compares criminal justice in South Carolina and Massachusetts. For a discussion of the essential role of communal opinion in criminal justice in Appalachia, see Altina L. Waller, Feud: Hatfields, McCoys, and Social Change in Appalachia, 1860-1900 (Chapel Hill, NC, 1988), 85-93.

8. Gregory H. Nobles, “Breaking into the Backcountry: New Approaches to the Early American Frontier," William and Mary Quarterly 46 (1989), 661. Regulator was the commonly used term in the eighteenth century for vigilantes.

9. Allan G. Bogue similarly suggested that cultural competition between southerners and Yankees may have played a role in claim club organization and violence, as claim club counties, located in the east central portion of the state and settled during the 1830 s and 1840 s, tended to have mixed populations of southerners, Yankees, and foreign immigrants. Bogue, "Iowa Claim Clubs," 235. In the 1860 census, most Iowans claimed a nativity in Ohio, Indiana, Illinois, Pennsylvania, or New York. On the eve of the Civil War, lesser but nonetheless significant numbers of Iowans had been born in Virginia, Kentucky, Missouri, Tennessee, and North Carolina. William J. Petersen, The Story of Iowa: The Progress of an American State, 2 vols. (New York, 1952), 1:357. Tensions between southerners and Yankees also profoundly shaped the political culture and social fabric of antebellum Illinois. James E. Davis, Frontier Illinois (Bloomington, IN, 1998), 3, 247-51. 
THE 1857 EASTERN IOWA VIGILANTE MOVEMENT and the responses to it reflected the legal and social context of the late midwestern frontier. Organized criminals who stole stock and circulated counterfeit currency exploited a widely dispersed prairie population, nascent connections to markets that still relied largely on equine and maritime transportation (only small portions of eastern Iowa were connected to railroad lines and the East by 1857), and the lack of centralized banking and standardized currency exchange. Significant population increase and in-migration from different regions of the antebellum United States meant that social identities and networks and legal and cultural institutions were recently established and insecure, even as highly localistic neighborhoods provided the basis for cultural and political identification. ${ }^{10}$

Population growth between 1850 and 1860 was particularly dramatic in the three predominantly rural counties that formed the epicenter of the 1857 vigilante movement: during that decade Jackson County's population more than doubled, Cedar County's more than tripled, and Jones County's more than quadrupled. The two more urbanized counties on the periphery of the vigilantes' activities, Scott and Clinton, saw equally dramatic gains, with population multiplied by 1860 between four and six times what it had been a decade earlier. ${ }^{11}$

Amid this social flux, participation in vigilantism became a means of asserting an identity as a respectable property-holder

10. Iowa's population more than tripled in the 1850 s, from 192,000 in 1850 to 674,913 in 1860. Petersen, The Story of Iowa, 356. James E. Davis, Frontier Illinois, $181-82,319,333-36,422-23$, argues that the early years of settlement in Illinois in the 1820s and 1830s saw substantial communalism and republican civic participation in cultural and legal institutions, but that substantial in-migration in the late frontier era from the late 1830 s through 1850 s fragmented social cohesion and destabilized social institutions; the lethal vigilantism of regulator movements in Winnebago County in northern Illinois and in Massac County in the southern portion of the state ensued. For an analysis of the crucial role of neighborhood in shaping political identity on the late antebellum Oregon frontier, see Paul Bourke and Donald DeBats, Washington County: Politics and Community in Antebellum America (Baltimore, 1995), 251-95.

11. U.S. Census Bureau, Ninth Census of the United States, 1870: Population (Washington, DC, 1872). Cedar County grew from 3,941 in 1850 to 12,949 in $1860(371 \%)$; Jackson County from 7,210 to $18,493(256 \%)$; Jones County from 3,007 to 13,306 (442\%); Scott County from 5,986 to 25,959 (434\%); and Clinton County from 2,822 to $18,938(671 \%)$. 
collectively defending livestock and the reliability of market exchange against culturally marginal persons who threatened those commodities and ostensibly the very basis of prosperity on the agrarian frontier. Membership in a vigilante committee thus served both to define and to enact community, drawing distinctions between respectable agrarian proprietors and a supposedly parasitical rural criminal class that threatened honest livelihood in a recently planted and rapidly changing society.

However, vigilantism also pulled other individual and collective identities in antebellum eastern Iowa into focus, particularly around the issue of the sanctity of law. Vigilantes defined themselves as those who would step outside of law to ensure that the ultimate purpose of all law, self-preservation, was served. Their actions constituted a critique of legal institutions that, because of a growing emphasis on legal fairness and procedure and the novelty and tenuousness of social relationships, seemed to them incapable of expressing the will of the dominant residents of the community or of effectively keeping social order. At the same time, vigilantes defined those they flogged or hanged as members of a disrespectable criminal class, unworthy of citizenship or of the mutuality expected of good neighbors.

A third social group, including editors, entrepreneurs, Quakers, and members of the legal culture (such as judges and lawyers), placed their faith in due process law and respected the rights of those accused of crime. Due process advocates in antebellum Iowa argued that, even in light of the real problem of frontier criminality, the actions of the vigilantes were intolerable because they endangered the very foundation of a republican form of government: the willingness of citizens to defer to the governmental and legal institutions that they had created and could alter through the political process. These due process proponents also asserted their superior knowledge and judgment on the basis of their social class. Emphasizing individual conscience and humane conduct, they argued that the actions of mobs represented the ignorant majority tyrannically extinguishing the rights of the accused and the unpopular. For due process supporters on the late eastern Iowa frontier, only the safeguarding of the majesty of law could ensure that the rights of all would be protected and that a stable social order could be erected. 
THE WAVE OF COLLECTIVE VIOLENCE in eastern Iowa began on April 11 in Jackson County. A mob broke into the jail at Andrew and seized Alexander Gifford, who had murdered John Engles as the two had hunted together. The crowd told Gifford that he would be given a fair trial if he confessed. He admitted that he had killed Engles under the hire of two settlers who wished Engles dead because of what he knew about their role in a murder back in New York State. At this revelation the mob, members of which apparently composed the Iron Hills Vigilante Committee, quickly hanged Gifford. The next morning a mob surrounded the house of one of the two men implicated by Gifford in the murder, but local officials managed to safely take him away. ${ }^{12}$

Seven weeks later, on May 29, an armed party of 40 , led by H. K. Landis, the postmaster of Iron Hill, seized William Barger, Michael Carroll, and a purported horse thief from the jail at De Witt in Clinton County. Barger had allegedly shot and killed his wife in 1854 after she had applied for a divorce. The Iron Hills Vigilantes took the three prisoners across the Jackson County line to Andrew, where they hanged Barger in front of a large crowd that included women and children. The mob voted to wait on deciding whether to hang Carroll, whipped him, and then turned him over to law officers. They also whipped the other prisoner and banished him. ${ }^{13}$

12. In this article, I use, among other sources, the voluminous files of nineteenthcentury newspapers, old settlers' accounts, and local histories that Paul Walton Black collected in the early 1910s as he wrote a master's thesis on lynching in Iowa. Given the depth of Black's research and his proximity to the events he was studying, including the opportunity he had to correspond with persons who remembered them directly, Black's notes are an indispensable source on Iowa's history of collective violence. They are available in Special Collections, State Historical Society of Iowa, Iowa City, whose staff provided valuable assistance. For Gifford's lynching ("Grifford" in some accounts), see Paul Walton Black, "Lynchings in Iowa," lowa Journal of History and Politics 10 (April 1912), 187; Burlington Daily Hawk-Eye and Telegraph, 5/30/1857, in Black, "Lynching Research Notes," box 1, folder 5, "Vigilanice Committees"; Annals of Jackson County, Iowa, no. 1 (1905), 29-34, and no. 3 (1906), 68-75, in Black, "Lynching Research Notes," box 1, folder 8, "Lynching Research Materials."

13. Landis's initials are also given as "J. K." in some sources. Black, "Lynchings in Iowa," 190-91; Annals of Jackson County, Iowa, no. 1 (1905), 29-34, and no. 3 (1906), 68-75, in Black, "Lynching Research Notes," box 1, folder 8, "Lynching Research Materials"; Burlington Daily Hawk-Eye and Telegraph, 6/9/1857, ibid.; 
A series of incidents occurred in early summer, after a body of regulators organized in Cedar County. One of them, William Corry, accused his neighbor, Alonzo Page, of participating in a gang of horse thieves. The regulators ordered Page to leave the county, but he refused. During the night of June 18, the mob surrounded Page's house and shot and fatally wounded him. ${ }^{14}$ On June 24 vigilantes seized Bennett Warren and carpenters Charles Clute and Jacob Warner in Scott County, apparently accusing them of involvement in horse theft, and took them into Clinton County, where they convicted Warren in a lynch court and hanged him. They released Warner and Clute after they promised to leave the area. ${ }^{15}$ On June 27 regulators seized and fatally shot alleged thief Peter Conklin near Yankee Run in Cedar County. ${ }^{16}$ In Jones County on June 29, a mob seized a convicted horse thief who had been jailed at Anamosa and hanged him. ${ }^{17}$ Several days later, on July 2 , in Cedar County, a mob of approximately 200 broke into the jail at Tipton and seized Alonzo

Cedar County Advertiser, 6/13/1857 and 6/20/1857; Dubuque Weekly Express and Herald, 6/10/1857; Davenport Daily Iowa State Democrat, 6/2/1857. Sources are unclear on the crime that Michael Carroll was charged with.

14. Black, "Lynchings in Iowa," 192; Muscatine Daily Journal, 6/25/1857 and 7/3/1857, in Black, "Lynching Research Notes," box 2, Cedar County folder; Cedar County Advertiser, 6/27/1857. News later circulated that Page was innocent and that Corry had accused him out of a personal grudge.

15. Black, "Lynchings in Iowa," 192-94; Cedar Valley Times, 7/9/1857, in Black, "Lynching Research Notes," box 2, Clinton County folder; Cedar County Advertiser, 6/27/1857; Clinton Herald, 6/27/1857; Anamosa Weekly Eureka, 6/30/57; Davenport Gazette, quoted in Muscatine Daily Journal, 6/28/1857, in Black, "Lynching Research Notes," box 2, Wapello County folder; Dubuque Daily Times, 6/30/1857; Davenport Gazette, 6/27/1857, quoted in Burlington Daily Hawk-Eye and Telegraph, 7/1/1857, in Black, "Lynching Research Notes," box 2, Cedar County folder. Some accounts give Warner's first name as Benjamin. Some versions state that Warner was hanged, but a local history asserts that he failed to leave as the vigilantes had ordered and instead prosperously farmed in the area, acquiring a reputation for "honesty and fair dealing that is above reproach." For Charles Clute, see History of Cedar County, Iowa (Chicago, 1878), 362-65 (also available in searchable format in the Kinyon Digital Library at www.kinyon.com). In 1856 Clute had been arrested as an accomplice in horse theft and had been flogged by neighbors in Cedar County after his release due to a lack of evidence against him. Black, "Lynchings in Iowa," 184-85.

16. Black, "Lynchings in Iowa," 194.

17. Ibid. The source, a reprint of a report from the Anamosa Gazette, does not give the lynched man's name. 
Gleason and Edwin Soper, accused of stealing the horses of German and Bohemian farmers. After a lynch court trial, the mob hanged Gleason and Soper from a tree south of Lowden. ${ }^{18}$

Three days after the hanging of Gleason and Soper, Cedar County vigilantes hanged another horse thief on the outskirts of Tipton. The same day, July 5, a mob flogged a youth accused of stealing a horse in the vicinity of Fairview in Jones County. ${ }^{19}$ On July 10, in the same county, the Vigilance Committee reportedly accused a Dr. Long and his brother of participating in a gang of horse thieves. Long got away, but the mob reportedly hanged his brother and an alleged accomplice. ${ }^{20}$ Newspaper reports indicate that a mob of 300 seized Jack Parrott in Cascade in Dubuque County, near the Jones County line, on July 13, and hanged him. ${ }^{2 !}$ On July 14, Cedar County vigilantes tried, convicted, and hanged a man named Kelso and his alleged criminal associate in Cedar County. ${ }^{22}$ On July 21, in the same county, a Mechanicsville mob of 400 convicted an alleged horse thief and counterfeiter named Kieth in a lynch court and hanged him. The regulators searched for but did not find another alleged horse thief, John F. Cole. ${ }^{23}$

The eastern Iowa vigilante movement concluded its lethal activities on December 4 in Jones County. A band of regulators seized Hiram T. Roberts, an alleged horse thief and counterfeiter from Indiana who owned a farm in Jones County. The

18. History of Cedar County, 365-68; Black, "Lynchings in Iowa," 195; Cedar County Advertiser, 7/4/1857.

19. Black, "Lynchings in Iowa," 195; Muscatine Daily Journal, $7 / 6 / 1857$, in Black, "Lynching Research Notes," box 2, Cedar County folder. The sources for the Jones County incident are ambiguous as to whether the mob's victim died from the severe flogging of 70 lashes inflicted.

20. Black, "Lynchings in Iowa," 196; Dubuque Republican, $7 / 14 / 1857$, quoted in Burlington Daily Hawk-Eye and Telegraph, 7/18/1857, in Black, "Lynching Research Notes," box 1, folder 8, "Lynching Research Materials"; Anamosa Weekly Eureka, 7/21/1857. Muscatine and Dubuque newspapers reported these events, but the Eureka denied that the vigilantes had hanged the men.

21. Black, "Lynchings in Iowa," 197; Dubuque Weekly Express and Herald, 7/15/ 1857; Dubuque Daily Times, 7/13/1857.

22. Black, "Lynchings in Iowa," 197; Muscatine Daily Journal, 7/20/1857, in Black, "Lynching Research Notes," box 2, Cedar County folder.

23. Black, "Lynchings in Iowa," 198; Muscatine lowa Democratic Enquirer, $7 / 23 / 1857$, in Black, "Lynching Research Notes," box 2, Cedar County folder. 
vigilantes told Roberts that he would get a legal trial if he cooperated, but a small portion of them quickly hanged him even as a larger portion deliberated over how to handle the prisoner. The Jones County sheriff arrested six men in connection with the mob execution of Roberts: William Dallas, a 36-year-old farmer who was a native of Scotland and an early settler of Cedar County; Benjamin Freeman, a 56-year-old farmer from Ohio who had sojourned in Indiana before settling in Iowa; George Saum, a 43-year-old farmer from Ohio who had also spent time in Indiana and whose parents were apparently born in Maryland and Virginia; two Cedar Countians, Moses Bunker and William M. Knott; and a settler, Charles Williams, who would eventually migrate on to Texas. Two hundred Cedar County residents reportedly "accompanied" the six men and their attorney, Judge Samuel A. Bissell, to their preliminary examination, where the defendants were released on bonds "signed by not less than one hundred of the best citizens of Cedar and Jones Counties." A grand jury failed to return indictments against the men. A local historian explained that the vigilantes had done their best to ensure that key witnesses would not testify against the men and, moreover, "one of the grand jury was in full sympathy and accord with the movement to free the country from the presence of dishonest characters" while "several" other grand jurors were "indifferent" to the case. ${ }^{24}$

A CONTAGION of well-organized collective violence had seized eastern Iowa. The foremost of the movement's avowed goals, looming large in how sympathetic editors and subsequent local historians represented the meaning of the lethal violence to the world, was the response of respectable citizens to organized criminal activity that threatened farmers' livelihoods. Horse theft and counterfeiting were indeed serious problems on the late midwestern frontier. The former meant the expensive

24. Black, "Lynchings in Iowa," 199; Cedar County Advertiser, 12/12/1857; Anamosa Weekly Eureka, 12/8/1857; Muscatine Weekly Journal, 12/19/1857; Dubuque Weekly Express and Herald, 12/9/1857; History of Cedar County, 316-18, 368-69, 667, 668; Hale and Rome Townships, Jones County, 1856 Iowa State Census (trans. Richard Harrison), www.rootsweb.com/ iajones/census/56hale.htm, www.rootsweb.com/ iajones/census/56rome.htm, accessed 8/4/05. 
loss of the primary means of transportation essential to agricultural production and the nexus to the nascent market; the latter was a threat to the validity and stability of economic exchange.

Popular historians chronicling these events noted that the Mississippi River and its tributaries in eastern Iowa, a densely wooded riverine network in the antebellum era, were especially susceptible to the activities of criminal gangs of horse thieves, who could easily take horses out of the area and bring counterfeit currency in. Early historians such as Benjamin F. Gue argued that the vigilantes' activities were regrettable but necessary, effectively ending a serious problem of crime and disorder on the Iowa frontier. Popular historians followed the explanation given by sympathetic editors who had sought to justify the events as they happened. In their interpretation, the pioneers were forced to turn to harsh measures because embryonic frontier legal institutions were not sufficient to protect farmers' property and lives. Extralegal measures purportedly ended rampant criminality and paved the way for social order and a respect for law on the Iowa frontier. ${ }^{25}$

The conventional understanding of vigilante violence in frontier Iowa is not wholly in error. It is, however, simplistic and incomplete. Legal institutions in antebellum Iowa were fairly well developed, certainly by 1857 when the most concentrated and extensive vigilante violence occurred. Courts and law enforcement were more embryonic in the early 1840 s, when a previous spate of lethal vigilante violence had occurred in Iowa Territory.

One of the most extensive episodes of vigilantism had occurred in Jackson County in 1840 . On April 1, a posse led by a territorial legislator who had been born in Kentucky and had served in the Illinois legislature, Colonel Thomas Cox, and a Kentucky-born Whig sheriff, William A. Warren, sought to serve warrants against $W$. W. Brown and his associates. Brown had migrated from Michigan or Indiana and operated a hotel and grocery in Bellevue. Cox's faction accused him of leading a gang of thieves and counterfeiters. In January, James Mitchell,

25. Benjamin F. Gue, History of lowa: From the Earliest Times to the Beginning of the Twentieth Century, vol. 1, The Pioneer Period (New York, 1903), 336, 338, 350; Orville F. Grahame, "The Vigilance Committees," Palimpsest 6 (1925), 359-70. 
an associate of Cox, had murdered James Thompson, who was affiliated with Brown. As the large group led by Cox sought to serve the warrants on Brown, shots broke out. In the ensuing gun battle, Cox's group sustained four fatalities, while Brown and two of his associates were killed and six of Brown's men fled. The following morning, Cox's group led a large crowd that put Brown's remaining men on trial. In a vote, 42 men cast red beans in favor of flogging and 38 voted white beans for hanging. The mob gave Brown's associates 39 lashes and put them on a boat headed down the Mississippi River. ${ }^{26}$

Colonel Cox and his faction had prevailed in a prolonged dispute over the political leadership and social order of early Jackson County. Cox and his confederates complained that Brown had manipulated the criminal justice system, particularly juries and grand juries, to avoid legal sanction for criminal activities. Cox and his allies had signed a secret pact vowing to expel Brown from Bellevue. John V. Berry, who had served as prosecuting attorney in Jackson County and also as Brown's lawyer, wrote to Territorial Governor Robert Lucas, denouncing the calculated attempt of "The Sheriff, Judge of Probate, and the celebrated Col Cox" to drive out "a peaceable citizen of that place." Berry asserted, "The mob with their infamous leaders have since the killing been engaged in holding a citizens court, as they call it, and have tried and punished several individuals." A Jackson County grand jury failed to return indictments against the vigilantes. ${ }^{27}$

Most local historians of the affair have been influenced by the views expressed by Sheriff William A. Warren as he recalled the events in publications in the $1870 \mathrm{~s} .{ }^{28}$ Some local scholars have been sympathetic to the Bellevue vigilantes' argument that

26. Various primary source accounts of the so-called Bellevue War are in Susan K. Lucke, The Bellewue War: Mandate of Justice or Murder by Mob? (Ames, 2002). For a short synopsis of the events, see Black, "Lynchings in lowa," 172-75. For biographical details on William A. Warren and W. W. Brown, see Lucke, The Bellevue War, 38, 42, 189; for biographical information on Col. Thomas Cox, see F. I. Herriott, "The Nativity of the Pioneers of Iowa," in The Iowa Official Register for the Years 1911-1912 (Des Moines, 1911), 15.

27. Lucke, Bellevue War, 248, 49, 120, 134.

28. John C. Parish, "White Beans for Hanging," Palimpsest 1 (1920), 9-28; Lucke, Bellevue War, 61, 201. 
no legal remedy was available to redress Brown's alleged criminal activity. ${ }^{29}$ In fact, the evidence is ambiguous and can be read to suggest that Cox, Warren, and others sought to impose, violently if necessary, a particular vision of community leadership. Moreover, all parties to the events spoke of the difficulty of securing indictments and convictions from petit and grand juries in an unsettled social landscape where personal reputation and allegiances meant much. ${ }^{30}$

Less elaborate collective violence also had occurred in Iowa in the territorial and early statehood period. For example, in 1840 in the Dubuque lead mining region, a white mob described by a correspondent as "'loafers' and 'grogbruisers" accused an African American man named Nat of theft and flogged him to death. $^{31}$ In another instance, vigilantes reportedly accused John Wilson of horse theft, convened a court of "Judge Lynch" to try him, and left him dead on the prairie of Linn County in July $1849 .^{32}$

Even if legal institutions were sometimes disregarded in favor of deadly extralegal violence, they did exist in Iowa in the 1840 s. By contrast, in the Dubuque lead mines in the mid-1830s, where Iowa's history of extralegal collective violence began with the hanging of alleged murderer Patrick $O^{\prime}$ Conner in June 1834 , formal legal institutions did not yet exist. ${ }^{33}$ The miners who executed $\mathrm{O}^{\prime}$ Conner imitated the custom of a legal trial and execution in a locale where no statutory authority yet existed to validate the administration of criminal justice.

29. Lucke, Bellezue War, 270-92. Lucke claims that her valuable collection of documents examines the events from all perspectives. However, she consistently aligns with the vigilantes' viewpoint and undermines the arguments of the vigilantes' critics, even as she admits that the evidence is mixed.

30. John V. Berry complained to Governor Lucas that "the mob boast that they had all of the Grand Jury for the next court to act with them except Brown and that he was killed." Berry argued that it would be "impossible, if not impossible utterly useless, to hold a court in a community composed of such brutish béasts." Quoted in Lucke, Bellevue War, 121.

31. Chicago American, 9/18/1840. I am grateful to Scott Grau for this source.

32. Dubuque Weekly Miner's Express, 7/25/1849, in Black, "Lynching Research Notes," box 2, Linn County folder.

33. Eliphalet Price, "The Trial and Execution of Patrick O'Conner at the Dubuque Mines in the Summer of 1834," Annals of lowa 3 (1865), 566-74. 
Federal authorities responded to the events in Dubuque by incorporating Iowa later that year into Michigan Territory. In 1837 Iowa became part of Wisconsin Territory, and in 1838 Iowa became an independent territory; statehood followed in $1846 .{ }^{34}$ But in another setting in early Iowa where legal jurisdiction was ambiguous, emigrants on the Overland Trail assembled in May 1853 in Council Bluffs in an informal "Judge Lynch's Court" to convict Baltimore Muir of murder and then hang him. ${ }^{35}$

In contrast to the citizens of early Dubuque or the emigrants on the Overland Trail, the eastern Iowa vigilantes and their defenders in 1857 did not act in the absence of a legally constituted criminal justice system. Rather, they asserted that they turned to extralegal violence because the style of criminal justice practiced on the late midwestern frontier did not afford sufficient protection for settlers against a burgeoning criminal class. Vigilantes asserted that they had no choice but to turn to the natural law of self-preservation to achieve their ultimate goal of reinforcing the administration of law.

The Jackson County Vigilance Committee, led by H. K. Landis, postmaster of Iron Hill, who claimed that the committee was "composed of from three to four hundred citizens," adopted resolutions demanding that the state's criminal law be enforced in that county "to the very letter." The Iron Hills Vigilantes resolved to rigorously. investigate counterfeiting, horse theft, and murders committed in the county and asserted that they would be "governed" by the state penal code in this endeavor "so far as it is convenient." Moreover, the Jackson County regulators sought the resignation of county officials they accused of avoiding the prosecution of serious criminal cases "by going a duck hunting." The vigilantes promised to closely scrutinize the behavior of officials and the conduct of criminal prosecutions. They also demanded the apprehension and prosecution of

34. Dorothy Schwieder, Iowa: The Middle Land (Ames, 1996), 27-28, 34.

35. Pottawatamie County History, 101-3, in Black, "Lynching Research Notes," box 2, Pottawatamie County folder; Letters from H. H. Field (?) to Paul W. Black, 4/3/1910 and 10/20/1910, ibid. For a discussion of extralegal justice and policing among emigrants on the Overland Trail, see John Phillip Reid, Policing the Elephant: Crime, Punishment, and Social Behavior on the Overland Trail (San Marino, CA, 1997), 117-208. 
David McDonald, who along with a man named Jarrett had allegedly commissioned Alexander Gifford (who had been hanged by the regulators in April) to murder John Engles. ${ }^{36}$

Eastern Iowa editors interpreted the regulators' argument by means of a systematic critique of the legal system. The $\mathrm{Ma}$ quoketa Excelsior expressed some doubts about "mob law," but argued that "there are times when Vigilance Committees are very beneficial in clearing the county of desperadoes." The Maquoketa editor suggested that excessive concern for proper procedure and fairness in due process law had precipitated a crisis in Jackson County. "When Judges so construe the law as to give new trials to felons who have been many times convicted of the most outrageous of crimes-when convictions cannot be had, and all sorts of villains go scot free without fear of the law-it is then past endurance." Similarly, in its reporting of the lynching of Michael Carroll and William Barger, the Excelsior stressed that the court's decision to grant Barger a new trial and Carroll a change of venue had inspired the vigilante violence against those men. ${ }^{37}$

Other newspapers in eastern Iowa picked up this theme in responding to the vigilante movement. The editor of the Dubuque Express and Herald argued that the problem lay in the growing emphasis on due process, particularly the unwillingness of juries to convict on anything short of "the clearest evidence." "In consequence of this acquittal, the malefactor goes abroad into the community, fearless of the law, and regardless of any new evidence which may come to light. . . . either our criminal code, or the mode of executing it, must ere long, undergo a change. To the utter inefficiency of one or the other, or both, can be traced the causes of the disgraceful lynching scenes which have done dishonor to our country." Four months later, the Dubuque Express and Herald resumed this critique of the administration of criminal justice in Iowa. The Dubuque editor excoriated the weakness of jurors and the machinations of lawyers in the

36. Burlington Hawk-Eye and Telegraph, quoted in Dubuque Weekly Express and Herald, 6/10/1857. The name is given as John Ingle in this source, while other sources give the name as Engles.

37. Maquoketa Excelsior, quoted in Cedar County Advertiser, 6/20/1857; Maquoketa Excelsior, quoted in Anamosa Eureka, 6/16/1857. 
Hawkeye State, contrasting the unpredictability of American law unfavorably with the reputed efficiency and fairness of legal institutions in England. The Express and Herald blamed the "record [of] so many mob executions as have taken place within the last twelve months" on the unreliability of legal institutions in Iowa. ${ }^{38}$

Vigilantes and editors who defended their actions emphasized the incompetence and inconstancy of jurors, lawyers, prosecutors, and county officials because the actions of those parties to the administration of criminal justice were relatively unpredictable in a time and place where personal reputations and ideological and factional loyalties were recently formed and potentially malleable. ${ }^{39}$ Attitudes about due process law, the sanctity of property holding and the suppression of its infringement, and the reputations of neighbors were up for grabs and led to a variety of results in legal process. In contrast to the formal legal system, vigilantism offered the satisfaction of the swift, harsh, and collective punishment of those who had allegedly committed crimes.

EASTERN IOWANS who opposed the vigilantes shared their understanding that the events must be understood in the context of a stance on law. A "large number of the citizens" assembled at the Friends meetinghouse in Springdale in Cedar County on July 18, 1857, to form the Anti-Mob Law Association, which adopted a preamble and resolutions condemning the "lawless violence" of the "'Vigilance Committee.'" The group sought the legal punishment of "horse thieves and all other criminals," arguing that vigilantism imperiled the rights of all citizens in a democracy by abandoning the neutrality and rationality of law in favor of "summary vengeance." Echoing criticisms of mob actions that echoed throughout the antebellum era, the association resolved "that when a portion of the people, acting under excitement, may with impunity trample the laws of the country under foot to effect their purpose, the rights of the good citizens

38. Dubuque Weekly Express and Herald, 8/5/1857, 12/2/1857.

39. For an editorial linking the problem of "mob law and lynching" in Iowa to the way incompetent prosecutors and "badly constructed juries" thwarted the punishment of criminals, see Dubuque Weekly Express and Herald, 7/22/1857. 
of a free and enlightened government are no longer secure, but may be wrested from them by any puff of passion." The association further demanded that the press condemn the "mobocratic proceedings." Asserting a class division in opinion on vigilantism, the group argued that "the enlightened community" should withdraw its support for the portion of the press "which is not high-toned enough" to condemn the violence. The anti-vigilantes concluded with the wish that "all good citizens" protest and employ their "influence" against the violence and seek to lawfully punish it for "the peace, prosperity and welfare" of the community. ${ }^{40}$

The citizens who formed the Anti-Mob Law Association were not alone in condemning the vigilantes' abandonment of due process law. Other eastern Iowans participated in a debate that sought to define the nature of republican government and criminal justice on the late midwestern frontier. The editor of Davenport's Daily Iowa State Democrat offered an impassioned defense of republican legal institutions as he condemned the "butchery" of the "Jackson County Mob" and the "respectable journals" that defended them. In deploring the vigilantes' resort to extralegal executions, the paper compared their actions to the attacks hostile American Indians made on white settlers. Invoking a notion that was common among antebellum white Iowans that American Indians were culturally inferior to white Americans, the Democrat asserted that vigilantism was in fact barbarism that eschewed the institutions of civilized society in favor of private vengeance and social disorder.

40. Muscatine Daily Journal, 8/1/1857; Black, "Lynching Research Notes," box 1, folder 4, "Lynchings Anti-Mob Association." The association's resolutions were notated by its secretary, Thomas Winn, who would serve as a delegate to the Republican state convention a month later in Iowa City. See Cedar County Advertiser, 8/8/1857. A few months after its residents gathered to oppose vigilantism, the Quaker township of Springdale would shelter John Brown's band of paramilitaries as they prepared to raid western Missouri. Dykstra, Bright Radical Star, 195. For an analysis of antebellum rioting and vigilantism that connects a surge in lethal collective violence in the early to mid-nineteenth century to the American Revolution's unraveling of traditional notions of hierarchy, a newly ascendant ethos of democratic egalitarianism, and the rise of profound cultural and social divisions involving class, race, and ethnicity, see Gilje, Rioting in America, 60-86. 
The Chief danger to the peace and order of a people self governed, is their efforts to take the execution of the law into their own hands, from the authority legally constituted by them to perform the duties of preserving public order, punishing crime and redressing wrong. ... A combination of desperadoes, impatient of the necessary delays of the law in the administration of justice, and each having some private spite and malice to gratify, are more fearful than a band of brutal Indians let loose upon Society with reeking knife and dripping tomahawk. In its frenzy it confounds innocence with guilt, takes suspicions for proof and executes vengeance instead of justice upon the victims of its hate. ${ }^{41}$

The Maquoketa Excelsior also condemned the actions of the regulators who hanged William Barger, pulled down his corpse three hours later, and drove it in a buggy to Cobb's Hotel, where they placed "a slip of paper" in the corpse's hands that "called for dinner and horse feed." Although the Excelsior sympathized with the vigilantes' frustrations with the legal system, it argued that their actions unveiled their uncouth style and unrefined values. "Such are some of the natural out-croppings of this lower strata, in the midst of a community that boasts decency, some degree of refinement, and a modicum of Christianity. ${ }^{\prime 42}$

The disapproval and remorse with which some eastern Iowans responded to the actions of the vigilantes could also take a more private form. A man identified as the "son of Deacon Finch, of Massilon, Cedar County" had participated in the vigilante committee that voted to hang "Kelso and his comrade." Finch left before the hanging, but upon arriving home his mother asked him if the vigilantes had apprehended the men. He replied that they had and that he had voted to hang the men. His mother admonished him that "he ought not to take that which he could not give." Finch went out to "his plowing" and after "awhile ... he hitched his horse" and used one of the reins to hang himself from a tree. ${ }^{43}$

\section{Davenport Daily Iowa State Democrat, 7/2/1857.}

42. Maquoketa Excelsior, quoted in Burlington Daily Hawk-Eye and Telegraph, 6/9/1857, in Black, "Lynching Research Notes," box 1, folder 8, "Lynching Research Materials."

43. The account of Finch's suicide comes from the Anamosa Eureka, quoted in Davenport Daily Iowa State Democrat, 7/22/1857. 
Some officials publicly identified or participated with the vigilantes. That group included Iron Hills postmaster $\mathrm{H}$. K. Landis and Cedar County judges Samuel A. Bissell, a 45-yearold migrant from upstate New York, and Wells Spicer, a young Know Nothing from Illinois who was also editor of the Cedar County Advertiser. ${ }^{44}$ Other members of the political class, however, denounced the lawless violence.

On September 18, Judge William Tuthill, a 49-year-old early settler and banker who had been born and educated in New York City, delivered a charge to Jones County grand jurors that underlined the advantages of adhering to due process law. Admonishing the grand jurors to fully investigate the vigilante activities in the county, Tuthill stressed that law safeguarded "order and harmony in our government, prosperity in our social relations, and peace and security to the community at large." Tuthill asserted that if citizens were to determine merely on the basis of their opinions what was crime and how to punish it, "anarchy" and the "overthrow of the government would ensue." Reading the full text of the Fifth Amendment to the U.S. Constitution to the grand jurors, Tuthill emphasized the sanctity of due process protections. He castigated the vigilantes' recourse to hanging, arguing that their actions in fact were "wilfully and wickedly trampling upon and setting at naught that glorious Constitution, framed by our patriotic forefathers, that we have been taught to regard as the very foundation and bulwork [sic] of liberty and prosperity as a people, and perpetuity as a nation." Tuthill argued that the very continuation of American

44. Maquoketa Excelsior, quoted in Cedar County Advertiser, 7/25/1857. On Samuel A. Bissell, see www.members.aol.com/BissellGenealogy/BHAMI2-3b.html, accessed 8/2/2005. Spicer, the Advertiser's editor, also participated in a mass meeting at Big Rock that organized the "Protection Society," which apparently laid the groundwork for the Cedar County vigilantes' activities. Cedar County Advertiser, 7/4/1857. For more on Spicer's colorful career, which later included exonerating Wyatt Earp after the shootout at the O.K. Corral, see Dykstra, Bright Radical Star, 177. Postmaster H. K. Landis was elected as president of a vigilance committee formed at Iron Hills and led their regulator activities as "Captain." A vigilante committee formed at Emmeline included two ministers in leadership roles: Rev. Ewald Cooly as president and Rev. A. McDonald as treasurer. Annals of Jackson County, Iowa, no. 1 (1905), 29-34, in Black, "Lynching Research Notes," box 1, folder 8, "Lynching Research Materials." 
democracy depended upon the respect of citizens for the rule of law. ${ }^{45}$

Despite Judge Tuthill's impassioned plea, grand jurors failed to indict the regulators for their illegal actions in 1857. One grand jury blamed the vigilantism on an organized band of horse thieves active in the state and the difficulty of bringing them to justice in light of "our sparse population." The grand jurors petitioned the state legislature for a statute that would enable county judges to increase the awards for the conviction of horse thieves to the value of the stolen stock and the penalty of conviction to no less than ten years' imprisonment. Stressing what they sought in criminal justice, the grand jurors hoped that their suggestions might "secure certain, sure, expeditious, and effective justice." The abstract values inherent in due process law mattered less to them than the rapid suppression of horse theft. ${ }^{46}$

THE DISCOURSE surrounding the vigilantism in eastern Iowa in 1857 highlighted divergent political allegiances and ideologies along with perspectives concerning law. The resolutions that the Jackson County Vigilance Committee adopted excoriated not only the administration of criminal justice in the county but also the general conduct and policies of the clique of ex-Whigs and Republicans who held Jackson County offices. Deploring what they termed the "robbery" and "smuggling" of county bonds and the "Drainage Fund," the regulators argued, in tones redolent of the working-class and yeoman republicanism of Jacksonian Democracy, that the officeholders were in cahoots with the criminals who plagued eastern Iowa. The vigilantes resented the officeholders who were inclined "to carry their sway over the people of the county, and to roll in their silks and purple and wealth at the expense of the hard earnings of the farmer and the hard working mechanic. ${ }^{\prime 47}$

45. Anamosa Weekly Eureka, 6/30/1857. Judge Tuthill's biographical information is in History of Cedar County, 615.

46. Cedar County Advertiser, 9/26/1857.

47. Burlington Hawk-Eye and Telegraph, quoted in Dubuque Weekly Express and Herald, 6/10/1857. 
Replying to criticism from Republican newspapers in Bellevue and Maquoketa that it had unjustly maligned Jackson County officials and had backed vigilantism, a Democratic newspaper in Dubuque, the Express and Herald, urged Jackson County citizens to purge their county's offices of the "bad men" who had held office for "a series of years" and whose tenure was distinguished by excessive taxation, misappropriation of public funds, "tricks, mismanagement, negligence and corruptions." The Express and Herald argued that it had "not approved mobocracy" and indeed had "in a better spirit" done more to dissuade "further acts of public punishment, no matter how justly merited" than had the "foul sheets" of the Maquoketa $E x$ celsior and the Bellevue Republican. Support or apology for the vigilantes and their critique of the overly deliberative and procedural style of law supposedly practiced in the courts of the region thus coincided with Democratic rhetoric and ideology that stressed the virtues of laissez-faire economics and minimal government, versus the support for public institutions and moral reforms expressed by Whigs and then Republicans. ${ }^{48}$

This ideological split between Democrats and Republicans over vigilante violence became especially clear when Republican governor James W. Grimes-in a letter replying to Clinton County Sheriff W. H. Buchanan-strongly condemned the regulators and vowed to suppress the movement. Buchanan had informed the governor that he held warrants for the arrest of the persons who had hanged Bennett Warren. They constituted, he wrote, "'a very large combination' . . . [which] is supposed to number 'about 2,000 persons in Jackson and the adjoining counties.'" Grimes responded to the sheriff's query as to how he should proceed by "unhesitatingly" urging him to "serve the warrants in your hands and enforce the laws of the state." Grimes reminded Buchanan that he could call to his assistance all the men of his county, and that he could prosecute anyone who refused to serve in such a "force." If that was "not sufficient to execute the laws," a militia drawn from other counties could

48. Dubuque Weekly Express and Herald, 7/7/1857. For a cogent discussion of Democratic and Whig values and social bases in Iowa, see Robert Cook, "The Political Culture of Antebellum Iowa: An Overview," Annals of Iowa 52 (1993), 225-50. 
be called upon, and Grimes said he would "direct all the military companies in the state" to ready themselves. The governor asserted his unequivocal determination to end the vigilante violence.

I am resolved that so far as in me lies, this lawless violence, which under the plea of administering justice to horse thieves, sets at defiance the authorities of the State, and destroys all respect for the law, both human and divine, shall be checked. I shall have no hesitation, therefore, when officially advised of the exigency, to call out the entire military power of the State, if necessary, to crush out this spirit of rebellion, which has shown itself in your county.

Noting that he had also received correspondence "on this subject" from a county judge and other residents of Clinton County, the governor asked the sheriff to publicize his letter so that there would "be no doubt as to my opinions on the subject."

Democratic editors were not impressed by Grimes's denunciation of the regulator violence, scoring him for what they characterized as hypocrisy and a failure to understand the threat that criminal depredation posed to property holding in the eastern Iowa countryside. In their view, Grimes's commitment to law and order was highly selective, exposing Republicans' commitment to a reformist, expansive, and oppressive state, in contrast to the limited government protective of the rights of - white citizens that Democrats advocated. With the vigilante killing of five proslavery settlers in Kansas in 1856 by John Brown and his band of abolitionists fresh in mind, Davenport's Daily Iowa State Democrat recalled Grimes's advocacy of action against the proslavery "Border Ruffians" in Kansas and asserted that Grimes had incited mob violence "against the ruffians of Kansas in defiance of the laws of the union." The Davenport editor argued that the Republican Party's "Higher Law movement" opposing slavery had fomented a widespread revolt against law and social order, precipitated by "their repudiation of federal laws; their denunciation of the decisions of Federal Courts; and their doctrine of erecting a tribunal in each man's breast as a guide;--and the result has been, mobs, vigilance committees, and general social disorder, always the product of a disregard

49. Grimes's letter is reprinted in the Cedar County Advertiser, 7/25/1857. 
for law." A Dubuque Democratic editor wondered why Grimes expressed no sympathy for a rural populace rendered insecure by rampant criminality and an ineffective administration of criminal justice. The editor argued that a local government commitment that might involve the more rapid impressment of posses, more vigorous efforts in court by public prosecutors, and the clearing of vagrants from the countryside would be more likely to end regulator violence than the governor's interventionist approach.

Moreover, in the summer of 1857 Democratic newspapers conflated the Republicans' policies with lawlessness by arguing that provisions in a proposed new state constitution would exacerbate the problem. If approved, Democrats argued, the new constitution, drafted by a convention with a Republican majority, would nullify the extradition of criminals and fugitive slaves to other states and unwisely expand the right to a jury trial and the definition of who could testify as a competent witness in court. Democrats argued that the new constitution would put Iowa at odds with federal law and transform it into a haven for criminals and renegade slaves. ${ }^{51}$

Grimes may have backed away from his stance against mob violence in light of the strong opposition it provoked. When asked in August why he had not taken measures against a large mob that hanged the alleged murderer William B. Thomas on July 14 in Poweshiek County, he claimed that he had not been

50. Davenport Daily Iowa State Democrat, 7/15/1857; Dubuque Weekly Express and Herald, 7/29/1857. On May 23, 1856, John Brown and his band sought revenge for proslavery advocates' raid on Lawrence on May 21. Bruce Levine, Half Slave and Half Free: The Roots of Civil War (New York, 1992), 196-97. For Grimes's role in funneling arms to the "Free Staters" fighting proslavery forces in Kansas, see Dykstra, Bright Radical Star, 136-39.

51. Dubuque Weekly Express and Herald, 7/29/1857. On August 3 voters narrowly adopted the Republican-backed constitution, which also provided for the creation of a banking system and established a debt limit for local governments. The constitution extended to African Americans the right to a jury trial and to serve as a witness. Voters defeated a separate proposition on the same ballot as the constitution that would have extended suffrage to African Americans. For the race-baiting constitutional convention and political debate in 1857, which was dominated by the slavery question, see Leland L. Sage, A History of Iowa (Ames, 1974), 134-41; and Robert R. Dykstra, "Iowans and the Politics of Race in America, 1857-1880," in Marvin Bergman, ed., Iowa History Reader (Ames, 1996), 132-33. 
notified by anyone in that county. While reasserting his "utmost" intention to enforce the laws when they are "resisted in any county," Grimes expressed his respect for the prerogative of county officials. "It is not my business," he argued, "to regulate the affairs of the counties, or to interfere with anybody, or anything in any one of them, unless called upon to do so by the county authorities." ${ }^{12}$

ALONG WITH THE CULTURAL, ideological, and political conflicts that the regulator violence in 1857 embodied and elicited, the vigilantes' actions indicated a significant transition in patterns of collective violence in the United States. The eastern Iowa regulators' praxis of violence included both customary and novel elements linking older Anglo-American traditions of communal violence with newer procedures that would become characteristic of postbellum midwestern lynching. ${ }^{53}$ For example, the regulators flogged several of their victims. Communal flogging, typically with 39 lashes on the bare back, was among the most typical of popular punishments in the eighteenth and early nineteenth centuries. ${ }^{54}$ Sometimes the regulators held a vote among the crowd to determine whether a victim should be flogged or hanged. For instance, 30 vigilantes voted to whip Bennett Warren and 300 voted to hang him in Clinton County. ${ }^{55}$ Conducting a ballot accorded with republican principles and suggested the communal basis of summary justice. Sometimes, vigilantes suspended a victim merely to obtain a confession or to scare or intimidate the target of their violence, as they did to a man named Teedles in Jones County on July 8 . After the regu-

52. Muscatine Weekly Journal, 8/15/1857.

53. For traditions of collective violence and morals regulation in north Britain and the American backcountry, see David Hackett Fischer, Albion's Seed: Four British Folkways in America (New York, 1989), 765-76, 889-95.

54. South Carolina regulators flogged the alleged criminals they punished in the Carolina backcountry in the 1760s. Brown, Strain of Violence, 72-73. Seven decades later, in the early 1830s, a transitional vigilante movement, the Slickers of northern Alabama, led by a "Captain Slick," informally tried and flogged victims they accused of counterfeiting and other criminal behavior. James W. Bragg, "Captain Slick, Arbiter of Early Alabama Morals," Alabama Review 11 (1958), 125-34.

55. Muscatine Daily Journal, 6/28/1857, in Black, "Lynching Research Notes," box 1 , folder 8 , "Lynching Research Materials." 
lators hanged him and then "restored [him] to life," Teedles reportedly implicated many persons in counterfeiting and horse theft. ${ }^{56}$ Non-lethal hanging represented the collective power of regulators to demand the truth about wrongdoing from an alleged miscreant, but could also potentially spiral into a second, fatal hanging if a confession angered the mob.

The 1857 vigilantes were far more organized than the loosely assembled lynchers of postbellum Iowa. ${ }^{57}$ The 1857 regulators bound themselves to each other through bylaws pledging to suppress criminality and swearing oaths of loyalty, secrecy, and collective self-defense. ${ }^{58}$ Many of their performances of extralegal collective justice were also substantially more elaborate than lynchings in Iowa in the late nineteenth and early twentieth centuries. The regulators elected a captain, who directed their activities, and sometimes conducted full-fledged informal trials of the men they accused, to the extent of appointing a judge, jury, and attorneys and examining witnesses. ${ }^{59}$ Such comprehensive trial procedure, which evoked the legitimacy of legal forms while eschewing the meaningful protections of due process law, was absent from postbellum lynchings in the Midwest.

Finally, the eastern Iowa regulators' hanging of suspected horse thieves, murderers, and counterfeiters connected easily with Anglo-American traditions of regulating community morals.

56. Black, "Lynchings in Iowa," 196.

57. For the ritual of lynching in postbellum Iowa, see Michael J. Pfeifer, Rough Justice: Lynching and American Society, 1874-1947 (Urbana, IL, 2004), 44-49.

58. Annals of Jackson County, Iowa, no. 1 (1905), 29-34, in Black, "Lynching Research Notes," box 1, folder 8, "Lynching Research Materials"; Burlington HawkEye and Telegraph, quoted in Dubuque Weekly Express and Herald, 6/10/1857. For an analysis of mid-nineteenth-century midwestern vigilante movements and their constitutions, see Patrick Bates Nolan, "Vigilantes on the Middle Border: A Study of Self-Appointed Law Enforcement in the States of the Upper Mississippi from 1840 to 1880 " (Ph.D. diss., University of Minnesota, 1971).

59. See the accounts of the lynch trial of Jacob (a.k.a. Benjamin) Warner in Cedar County in Davenport Gazette, 6/27/1857, quoted in Burlington Daily Hawk-Eye and Telegraph, 7/1/1857, in Black, "Lynching Research Notes," box 2, Cedar County folder; and the lynch trial and execution of Bennett Warren in Clinton County in Cedar Valley Times, $7 / 9 / 1857$, ibid. In the latter case, a constable from Big Rock, Mr. Gates, observed the proceeding and told the regulators that Warren had been "convicted on the most slimy evidence I ever heard." Some of the mobbers threatened to hang him for his opposition, but the captain intervened to prevent violence against Gates. 
Such a practice was manifested in Cedar County in July 1857 amid the wave of violence against alleged murderers and property criminals. A Scottish-born farmer named John Chappell recounted in his diary on July 6 that a society had organized at Rogersville to protect members from horse thieves. Five days later, Chappell wrote that the "Regulators," led by "Capt. Wm. Dallas," seized and brought before "Judge Lynch" a man named David Winterringer. They tried the suspect "before Squire Rigby, Elder Ferguson and Samuel Yule and others for the hinous [sic] offence of asking and attemptimg [sic] to take a kiss of Miss Smith, schoolmadam at the Brick school house, Red Oak." At first, the regulators "could not make out an evil case of it." But after "serious advice from Elder John Ferguson," the "company" extracted a confession, although "the prisoner" continued to laugh about the matter. But when "Capt. Dallas" displayed a rope, Winterringer cried "tears of penitence" and soon "agreed to leave the county of Cedar forever under the pain of having his head bored by a bullet." ${ }^{\prime 60}$

The Red Oak regulators were well-established farmers who had been among the first white settlers of Cedar County; Chappell, Dallas, Ferguson, Yule, and Rigby had arrived in 1837 and 1838. At least four of them had been born in Scotland and had migrated to America in the late 1820 s and in the early to mid1830s. Three of the future vigilantes had sojourned in New York and Indiana and one in Ohio before arriving in frontier Iowa; one of them, William Dallas, would be arrested six months later for his role in the vigilante murder of Hiram Roberts, whose death concluded the 1857 eastern Iowa vigilante movement. ${ }^{61}$

Informal, communal scrutiny and punishment of offenses that violated prevailing gender and sexual standards was a common feature of rural American, British, and European society in the early modern era. ${ }^{62}$ But the custom transmogrified into nearly lethal regulator violence in the context of a flurry of

60. "John Chappell's Diary," Cedar County Historical Review (July 1984), 97-98.

61. History of Cedar County, Iowa, 316-18, 667, 668, 672, 368-69.

62. Natalie Zemon Davis, "The Reasons of Misrule," in Society and Culture in Early Modern France: Eight Essays by Natalie Zemon Davis (Stanford, CA, 1975), 97-123; E. P. Thompson, "'Rough Music': Le Charivari Anglais," Annales: Economics, Societies, Civilization 27 (1972), 286-87. 
deadly vigilantism on the late midwestern frontier. The coerced confession, threat to hang and shoot, and forced exile of a man who had apparently illicitly kissed an unmarried schoolteacher in Cedar County illustrated not only the continuity of practices of informal violence into the mid-nineteenth-century Midwest, but also how the 1857 eastern Iowa vigilante movement moved in important directions away from tradition.

The 1857 movement was highly lethal. Although it did not always kill its victims, it often employed deadly violence that sought to kill, not merely physically chastise, the people it targeted. Most regulator movements in the American backwoods in the eighteenth and early nineteenth centuries did not seek to kill their victims, although the targets of earlier popular violence sometimes died from the severe wounds inflicted in floggings. In a decisive and well-publicized turn towards lethality, vigilantes in Vicksburg, Mississippi, in 1835 had hanged five gamblers. As Americans arrived in California in the late 1840s and in the 1850s, they, too, employed rampant vigilante hangings in their cultural conquest of California and in their contest for social power in the gold mines and in burgeoning cities such as San Francisco. ${ }^{63}$ The eastern Iowa regulators in 1857 also played a crucial role in this lethal transition in lynching violence that occurred throughout the United States beyond the Allegheny Mountains in the antebellum era. The eastern Iowa vigilantes fatally hanged and shot 16 men, and their lethal actions bequeathed an important legacy of deadly communal murder, most often through hanging, to postbellum midwestern lynch mobs.

Significantly, the regulators in eastern Iowa in 1857 helped to initiate a revolt against due process law through lynching that would cascade throughout the postbellum Midwest, West, and South. Over succeeding decades, lynchers would collec-

63. Christopher Waldrep, The Many Faces of Judge Lynch: Extralegal Violence and Punishment in America (New York, 2002), 28-31, 50-56; Robert M. Senkewicz, Vigilantes in Gold Rush San Francisco (Stanford, CA, 1985); David Johnson, "Vigilance and the Law: The Moral Authority of Popular Justice in the Far West," American Quarterly 33 (1981), 558-86. Although the rampant lynching in California in the $1850 \mathrm{~s}$, particularly the 1856 San Francisco vigilante movement, was well publicized nationally, Iowa sources from 1857 do not mention events in the Far West as an inspiration for the eastern Iowa regulator violence. 
tively murder several thousand people across the country in their commitment to a vision of harsh, rapid, and communal justice that rejected a growing emphasis on legal safeguards and humanitarian reforms of the criminal justice system. ${ }^{64}$ The 1857 vigilantes and their opponents in eastern Iowa were obsessed with the rule of law. Although they differed vehemently over the role of law and the state and the nature of legal institutions and punishment, they shared a common language of republican citizenship and the desire to create a society in which law would be respected and social order would ensue. Contemporary Iowans and other Americans who ponder the effectiveness and fairness of criminal justice institutions bear the legacy of the debate over the nature of law, punishment, the demands of society, and individual rights that surged so vividly across the prairie of eastern lowa in 1857.

65. Pfeifer, Rough Justice. Lynch mobs would collectively murder 24 men and unsuccessfully try to lynch at least 52 persons in Iowa between 1874 and 1909. 
Copyright of Annals of Iowa is the property of State of Iowa, by \& through the State Historical Society of Iowa and its content may not be copied or emailed to multiple sites or posted to a listserv without the copyright holder's express written permission. However, users may print, download, or email articles for individual use. 